\title{
FLAVONOIDS NUTRACEUTICALS IN PREVENTION AND TREATMENT OF CANCER: A REVIEW
}

\author{
ROBERT LOTHA, ARVIND SIVASUBRAMANIAN*
}

Department of Biotechnology, School of Chemical and Biotechnology, Sastra University, Thirumalaisamudram, Thanjavur, Tamil Nadu, India. Email: arvi@biotech.sastra.edu

Received: 05 September 2017, Revised and Accepted: 24 October 2017

ABSTRACT

The objective of the study was to discuss the preventive and treatment of cancer from flavonoids nutraceuticals from our daily dietary source. There has been increasing interest in the research of flavonoids from dietary sources, due to growing evidence of the versatile health benefits of flavonoids through epidemiological studies. Numerous biological activities have been reported. Some clinical trials or meta-analyses have suggested positive associations between flavonoid intake and human health, Several findings have proven that dietary flavonoids to have anticancer properties. Flavonoids due to their nontoxicity in nature and vast, broad aspect of its benefits in biological activities have been intensively studied for their health benefits also added to its abundant availability in our daily diets, for example, green leaves, fruits, red wine, and tea vegetables.

Keywords: Medicinal plants, Flavonoid, Cancer prevention, Antiproliferation, Apoptosis, Antioxidative, Multidrug resistance, Angiogenic.

(C) 2018 The Authors. Published by Innovare Academic Sciences Pvt Ltd. This is an open access article under the CC BY license (http://creativecommons. org/licenses/by/4. 0/) DOI: http://dx.doi.org/10.22159/ajpcr.2018.v11i1.22410

\section{INTRODUCTION}

Plants have been the backbone and foundation source of medicines since time immortal, although there has been a remarkable advancement achieved in modern pharmacology and in the field of synthetic organic chemistry, the dependency to acquire medicine through natural products still remain unchanged [1]. Given facts that in medical history the very origin of the reservoir for finding new promising and potential drugs is from plant source [2]. Recent years have shown an immense interest in herbal drugs and traditional treatments toward illness, disease, and the upsurge of its scientific studies worldwide will continue for many years to come [3]. Flavonoids are secondary metabolites polyphenolic compounds that are omnipresent in plants and as many, as more than 4000 broadly classified polyphenolic are known [4]. Since the ubiquitous presence of flavonoids in our daily diet, it is vital to evaluate its source in our food which acts as antioxidants. Due to vast health benefits are proven through the epidemiological investigation, there are increasing ongoing research about flavonoids and its impact on human health [5]. The evidence from some clinical trials suggested a positive link between human health and flavonoid intake. Now it is clear that flavonoids or many of its derivatives are acting as a chemoprevention to many common types of cancer [6]. The preventive and protective nature of flavonoids is related to their strong anticarcinogenic potential, antimutagenic, and antiproliferative [7]. They are abundantly present in all dietary vegetables and fruits (Table 1), intake of flavonoids in an average is estimated to be few $100 \mathrm{mg}$ daily [8]. These compounds have displayed remarkably in almost all the area of biological activities, which might influence the dysregulated of normal processes during cancer progression. Those include antiproliferative, modulation of enzymatic activities and anti-inflammatory $[9,10]$.

Along with numerous health benefits, flavonoids can be seen as an alternative to therapeutic agents for prevention of cancer or in chemopreventive $[11,12]$. In this review article mainly generalize the older and recent approaches toward treating cancer through nutraceutical flavonoids by analyzing numerous research finding on this topic.

\section{FLAVONOIDS AND ITS ANTICANCER ACTIVITY}

Epidemiological evidence on flavonoids

The data collected from approximately 200 studies that analyze the relationship of vegetable and fruits and different type of cancers are observed which shows exceptional improvement [13] there has been a rise of prostate cancer in the present alarming [14], participants of 477,312 adult men and women from 10 European countries. Initially, classified total dietary flavonoids intakes and individual subclasses were examine through questionnaires from center-specific validated dietary and compositing data that are collected from the PhenolExplorer database. During an average of 11 years of follow-up, new cases of 4517 primary colorectal cancer (CRC) were identified, of which among 2869. There were1648 rectal and colon tumors (proximal=1298 and distal=1266). No association between any CRC subtype and total flavonoid intake and also among individual flavonoid intake subclasses. Consumption of total flavonoids and its subclasses, examine from dietary questionnaires, does not prove to have shown an association with CRC development [8]. However, there have been few contrary reports of which states otherwise for nonassociation between flavonoids intake with subsequent cancer cause, in most of the epidemiological investigation [4].

\section{Flavonoids: In vitro studies}

The summarized reports on flavonoids against various diverse cell systems conducted in vitro and its inhibitory properties of potential anticancer activity are shown in Table 2 .

\section{Flavonoids: Clinical trials on human}

The promising results of anticancer effects in preclinical studies have encouraged clinical trials of flavonoids inhuman. Phase I and pharmacological investigation of flavone acetic acid were conducted in early 1988, one among series of novel flavonoids tested [26].

Quercetin a flavonoid is occurring naturally with many biological activities, a dose-escalating Phase I was performed by Ferry and was found to suppress lymphocyte tyrosine kinase in 9 of 11 patients investigated. During the course of 3-week treatment with four low doses of quercetin $\left(60 \mathrm{mg} / \mathrm{m}^{2}\right)$ intravenous one patient with hepatocellular carcinoma had developed a fall in alkaline phosphatase and serum alpha-fetoprotein. A stage four ovarian cancer patient with who had not responded to six courses of cisplatin/cyclophosphamide chemotherapy shows fall in CA125 tumor marker from 295 to 55 units/ml after two treatments of intravenous quercetin $\left(420 \mathrm{mg} / \mathrm{m}^{2}\right) 3$ weeks apart. The authors concluded to $1400 \mathrm{mg} / \mathrm{m}^{2}$ as bolus dose, which can 
Table 1: Dietary source and subclasses of flavonoids

\begin{tabular}{lll}
\hline Flavonoid subgroup & Representative flavonoids & Major food sources \\
\hline Flavanonols & Taxifolin & Limon, aurantium \\
Flavanones & Eriodictyol, hesperitin, naringenin & Oranges, grapefruit \\
Flavanols & Catechin, gallocatechin & Apples, tea \\
Isoflavones & Daidzein, genistein, glycitein, formononetin & Soya beans, legumes \\
Flavones & Apigenin, chrysin, luteolin & Parsley, thyme \\
Flavonols & Kaempherol, myricetin, rutin, quercetin & Onions, cherries, apples, kalebroccoli, tomato, berries, tea, red wine, \\
& & tartary buckwheat \\
\hline
\end{tabular}

Table 2: Flavonoids and its anticancer activities on different types of cancer cell lines

\begin{tabular}{|c|c|c|c|}
\hline Cancer & Cell & Flavonoid & References \\
\hline Human oral cancer & HSC-2, HSG, SCC-25 & $\begin{array}{l}\text { Flavanones, isoflavans, quercetin, EGC, chalcones, EGCG, curcumin, } \\
\text { genistein, ECG }\end{array}$ & Refs.[15] \\
\hline Human breast cancer & MCF-7 & Flavanones, daidzein, genistein, quercetin, luteolin & Refs.[16] \\
\hline Human thyroid cancer & ARO, NPA, WRO & Genistein, apigenin, kaempferol, chrysin, luteolin, biochanin A & Refs.[17] \\
\hline Human lung cancer & $\begin{array}{l}\text { SK-LU1, SW900, H441, H661, } \\
\text { haGo-K-1, A549 }\end{array}$ & Flavone, quercetin & Refs.[18] \\
\hline Human prostate cancer & LNCaP, PC3, DU145 & $\begin{array}{l}\text { Catechin, epicatechin, quercetin, kaempferol, luteolin, genistein, } \\
\text { apigenin, myricetin, silymarin }\end{array}$ & Refs. $[19,20]$ \\
\hline Human colon cancer & Сaco-2, HT-29, IEC-6, HCT-15 & Flavone, quercetin, genistein, anthocyanin & Refs.[21,22] \\
\hline Human leukemia & HL-60, K562, Jurkat & Apigenin, quercetin, myricetin, chalcones & Refs. $[23,24]$ \\
\hline B16 mouse melanoma & $4 \mathrm{~A} 5$ & Chalcones & Ref.[25] \\
\hline
\end{tabular}

EGCG: Epigallocatechin gallate, ECG: Epicatechin gallate, EGC: Epigallocatechin

be administered either at weekly intervals or over 3 weeks. Phase II trials. $1700 \mathrm{mg} / \mathrm{m}^{2} 3$ weekly asset as the maximum tolerated dose however the vehicle, dimethyl sulfoxide was found to be unsuitable [27]. A pro-drug of quercetin ( 30 (N-carboxymethyl) carbomyl-3,4 0,5,7-tetrahydroxyflavone) also known as QC12 which was synthesized went through initial Phase I trial IV, dose-escalation studies [28].

\section{Inhibit carcinogen metabolic activation}

One of the main important mechanism of how flavonoids may strive their anticancer activities are through their interaction with Phase I metabolizing enzymes, e.g., cytochrome P450, which metabolically activate and initiate vast numbers of procarcinogens reactive intermediates that can result to interact with cellular nucleophiles and finally cause carcinogenesis. Flavonoids hinder activities of isozymes (P450) such as CYP1A1 and CYP1A2 [29,30].

\section{Antiproliferation}

Antiproliferation can be achieved by inhibition of prooxidant agents that initiate tumor promotion, generally reactive oxygen species (ROS) a growth promoting oxidants acts as the main catalyst for progression and promotion of tumor to initiation stage, i.e., carcinogen metabolic to mutagens. Tumor promoters such as lipoxygenases and arachidonate metabolizing enzymes, and cyclooxygenases which are phorbol esters activate or induce prooxidant and flavonoids are specifically effective at xanthine oxidase inhibition [31].

\section{Cell cycle arrest}

Disruption in cell cycle advancement may result in the anticancer effects of flavonoids. Mitogenic signals execute cells to enter into a series of regulated steps allowing traverse of the cell cycle. During S phase synthesis of DNA occurs which separates into two daughter cells in M phase are the core features of progression in the cell cycle. The G2 phase occurs between the time of $\mathrm{S}$ and $\mathrm{M}$ phases, any errors to DNA during duplication are repaired during this phase stopping further propagation of these errors cells to daughter cells. In contrary, the G1 phase represents the duration of commitment to cell cycle progression that separates $\mathrm{M}$ and $\mathrm{S}$ phases as cells prepare for DNA duplication that further progress to mitogenic signals [4]. Cyclin-dependent kinases (CDKs) have been identified and act as the key regulators of progression in the cell cycle, deregulation and alteration of CDK activity are hallmarks of pathogenic resulting to neoplasia. A numerous of cancers is associated with mutation of the CDK genes or CDK inhibitor genes, as a result, causes hyperactivation of CDKs. Hence, modulators or inhibitors can be of great interest to explore as novel therapeutic agents in cancer prevention and treatment $[32,33]$.

\section{Induction of apoptosis}

Flavonoids have been known to induce cell death (apoptosis) in some cancer cell lines, while normal cells are spared. The molecular mechanisms by which flavonoids initiate apoptosis have not yet been fully understood. There can be several mechanisms factors that may be involved, which may include inhibiting the activity of DNA topoisomerase I/II activity, [23,34-36] and decrease in the ROS [37].

\section{Initiation of differentiation}

The flavones phloretin, quercetin, luteolin genistein, apigenin, and isoflavone daidzein were found to induce differentiation of human acute myelogenous leukemia HL-60 cells into monocytes and granulocytes [38,39]. Cancers cells arise by harboring mutated cells that initiate the need for exogenous growth factors. Abnormality of growth control ultimately results in the selection of clonal lines of cells that replicate at the pace of embryonic stage and yet fail to respond to maturation signals and differentiation. The nonphysiological promoter of terminal differentiation has been used as novel therapies approach toward cancer therapy and prevention. Initiation of terminal differentiation by flavonoids may result in ultimate elimination of tumorigenic cells and maintaining balance of homeostasis in a normal cell. Therefore, flavonoids could be developed into promising alternative as anticancer agents [4].

\section{Antioxidative activity of flavonoids}

Dietary flavonoids act as natural antioxidants [40] against cancer may be through the limit of damaging oxidative reactions in mutated cells, which may incline to the development of carcinoma. Oxygenderived free radicals possess the properties to promote and initiate to carcinogenesis. Mainly lipid peroxidation products which originate from dying cells could also lead to a cancer promotional effect [41].

\section{Prohibit angiogenic process}

Flavonoids which are also known as angiogenesis inhibitors are source from nature [42]. 
Table 3: A recently published articles attribute some specific flavonoids or their derivatives promote cell apoptosis in cancer cells involving throughout mechanisms for the synthesis of ROS

\begin{tabular}{|c|c|c|c|c|}
\hline Cell line & Molecules & Results & Mechanism of action & Refs. \\
\hline B16-F10 (melanoma) & Quercetin & $\begin{array}{l}\text { The pro-apoptotic effects of low } \\
\text { doses of quercetin }(10-20 \mu \mathrm{M}) \text { in } \\
\text { UVB-irradiated melanoma cells are } \\
\text { mediated through the increase of } \\
\text { ROS, calcium homeostasis imbalance, } \\
\text { and modulation of antioxidant } \\
\text { defense }\end{array}$ & $\begin{array}{l}\text { Quercetin attenuated MEK-ERK } \\
\text { and Akt/PI3 K signaling and } \\
\text { enhanced the UVB-induced NF- } \mathrm{B} B \\
\text { nuclear translocation }\end{array}$ & [48] \\
\hline U20s (osteosarcoma) & RWP & $\begin{array}{l}\text { RWP induced Type I/II mixed cell } \\
\text { death in a dose-dependent manner } \\
\text { with a maximum effect in the range } \\
\text { of } 100-200 \mu \mathrm{g} / \mathrm{ml} \text { equivalents of } \\
\text { gallic acid }\end{array}$ & $\begin{array}{l}\text { RWP mechanism was } \\
\text { independent of its antioxidant } \\
\text { activity and involved the } \\
\text { inhibition of PI3K/Akt kinase } \\
\text { signaling }\end{array}$ & [49] \\
\hline SW480 (colorectal cancer) & Silibinin & $\begin{array}{l}\text { Silibinin rapidly increased oxidative } \\
\text { stress in SW } 480 \text { cells due to ROS } \\
\text { induced and generation apoptosis } \\
\text { and autophagy mixed phenotypes }\end{array}$ & $\begin{array}{l}\text { Silibinin strongly inhibited } \\
\text { pathway of PI3/Akt/mTOR but } \\
\text { activatedMAP2K1/2-MAPK1/3 } \\
\text { signaling for its biological effects }\end{array}$ & {$[50]$} \\
\hline MDA-MB-468 (breast cancer) & Luteolin, apigenin, & Inhibit cell proliferation and induce & Intracellular copper mobilization & [51] \\
\hline BxPC-3 (pancreatic cancer) & EGC-3-gallate, and & apoptosis & and ROS generation by the tested & \\
\hline PC3 (prostate cancer) & resveratrol & & $\begin{array}{l}\text { compounds leading to cancer cell } \\
\text { death }\end{array}$ & \\
\hline A549 (Lung cancer) & $\begin{array}{l}\text { Curcumin mono-carbonyl } \\
\text { analogs (diarylheptanoids) }\end{array}$ & $\begin{array}{l}\text { Cytotoxic and proapoptotic } \\
\text { mechanisms }\end{array}$ & $\begin{array}{l}\text { Compound A1 convert TrxR } \\
\text { antioxidant enzyme into an ROS } \\
\text { promoter, resulting in a burst of } \\
\text { the intracellular ROS. The ROS } \\
\text { generation is associated with } \\
\text { apoptosis }\end{array}$ & {$[52]$} \\
\hline Jurkat cells (T cell leukemia) & $\begin{array}{l}\text { Tetrahydroxy-trans-stilbene } \\
\text { derivatives (M6, M8, M12) }\end{array}$ & $\begin{array}{l}\text { Cytotoxic activity and increased } \\
\text { activity of caspase } 3 \text { and } 9\end{array}$ & $\begin{array}{l}\text { Cell death was accompanied by } \\
\text { loss of mitochondrial potential, } \\
\text { oxidative stress, decrease of } \\
\text { glutathione level as well as } \\
\text { loss of both mRNA expression } \\
\text { and activity of superoxide } \\
\text { dismutase (MnSOD) }\end{array}$ & {$[53]$} \\
\hline B16-F10 (melanoma) & ECG analogue JP8 & $\begin{array}{l}\text { JP8 induces apoptosis and autophagy } \\
\text { in B16-F10 melanoma murine cells } \\
\text { but not in normal cells, through ROS } \\
\text { generation }\end{array}$ & $\begin{array}{l}\text { JP8 preferentially induces cell } \\
\text { death (Type I/II) in cancer cells } \\
\text { by increasing ROS generation and } \\
\text { inducing stress-related proteins } \\
\text { such asIRE1 } \alpha, \text { p-elF2a and CHOP }\end{array}$ & {$[54]$} \\
\hline $\begin{array}{l}\text { Hepatocellular, pancreatic, } \\
\text { beast, glioblastoma cancer } \\
\text { cell lines }\end{array}$ & $\begin{array}{l}\text { DPP } 23 \text { (novel synthetic } \\
\text { polyphenol conjugate) }\end{array}$ & $\begin{array}{l}\text { DPP } 23 \text { increases ROS generation and } \\
\text { trigger apoptosis in cancer cell lines } \\
\text { without effects in normal cells }\end{array}$ & $\begin{array}{l}\text { DPP } 23 \text { activates the UPR in } \\
\text { the endoplasmic reticulum } \\
\text { through ROS generation and } \\
\text { caspase-dependent apoptosis } \\
\text { selectively in transformed cells }\end{array}$ & {$[55]$} \\
\hline
\end{tabular}

ROS: Reactive oxygen species, RWP: Red wine polyphenols, MAPK: Mitogen-activated protein kinases, UPR: Unfolded protein response, NF-кB: Nuclear factor-kappaB, PI3K: Phosphoinositide 3-kinase, ERK: Extracellular regulated protein kinases, EGC: Epigallocatechin

In the healthy adult, human body angiogenesis is a strictly controlled process and is regulated by different endogenous angiostatic and angiogenic factors. Still, in cancer, pathological angiogenesis can occur when proper vascularization is deprived, due to the lack of diffusion of oxygen and nutrients in the cells. Apoptosis occurs to balance the high proliferation rate in the tumor. Flavonoids are able to interfere with various steps of angiogenesis as inhibitors such as lumen formation, migration of endothelial cells, proliferation, and basement destruction of blood vessels. Hence, can be potential compounds for the treatment of tumors [42,43].

\section{Multidrug resistance (MDR) modulation}

Some specific flavonoids are known to possess potent inhibitory activity against the drug-exporting activity of P-glycoprotein, adenosine triphosphate (ATP)-binding cassette (ABC) a plasma membrane transporter that evicts drugs which are cytotoxic at the expense of ATP hydrolysis. P-glycoprotein has two homologous portions each containing a transmembrane domain (TMD) involved in drug efflux and binding, and the other half a cytosolic nucleotide-binding domain (NBD) involved in ATP hydrolysis and binding, with domain topology of an overall (TMD-NBD) 2. Modulation by flavonoids toward cell MDR mediated by P-glycoprotein may be caused by inhibiting the overexpression of MDR-1 [44].

\section{Novel biological effects with natural killer cells}

Natural killer (NK) cells were discovered as naturally occurring killer lymphocytes toward mouse Moloney leukemia cells. NK cells may function to remove virally infected and transformed cells [45]. In principle, if malignant cells escape immune surveillance, or suppress the function and numbers of NK cells, it could lead to development and establishment of cancer. In support of this idea, dysfunction and abnormal NK cells were observed in cancer patients including (i) reduced cytotoxic activity, (ii) down-regulated expression of activating receptors, cytokine, and intracellular signaling molecules, and (iii) attenuated cell proliferation [46]. 
Table 4: List of flavonoids with their molecular targets and chemopreventive effects

\begin{tabular}{|c|c|c|c|}
\hline Phytochemical & Chemopreventive effect & Molecular targets & Biological effect \\
\hline \multirow[t]{4}{*}{ Tangeretin } & Suppression of carcinogenesis & c-Src CYP1A2 & Inhibit the activity (in silico study) upregulation \\
\hline & Cell cycle regulation & p53, p21, p37 & on COLO 205 cells G1 arrest in MCF-7 cells \\
\hline & Apoptosis & p53 & Trigger apoptosis in COLO 205 cells Induce apoptosis on HL-60 cells \\
\hline & Angiogenesis and metastasis & ERK-2 HIF1- $\alpha$ & Inhibit the activity (in silico study) \\
\hline \multirow[t]{2}{*}{ Nobiletin } & Suppression of carcinogenesis & c-Src CYP1A2 & Inhibit the activity (in silico study) \\
\hline & Angiogenesis and metastasis & ERK-2 HIF1- $\alpha$ & Inhibit the activity (in silico study \\
\hline \multirow[t]{4}{*}{ Hesperidin } & Suppression of carcinogenesis & PI3K & Inhibit the activity (in silico study) \\
\hline & Cell cycle regulation & CDK2 & Inhibit the activity (in silico study) \\
\hline & Apoptosis & p53 & Upregulation on MCF-7 cells \\
\hline & Co-chemotherapeutic & PgP, Bcl-2, Bax & $\begin{array}{l}\text { Inhibit the activity (in silico study) increase cytotoxicity of } \\
\text { doxorubicin on MCF-7 cells by modulating cell cycle and induce } \\
\text { apoptosis Downregulation on HeLa cells. Upregulation on HeLa cells }\end{array}$ \\
\hline \multirow[t]{2}{*}{ Hesperetin } & Cell cycle regulation & CDK2, CDK4, Cyclin D & Downregulation on MCF-7 cells \\
\hline & Apoptosis & Caspase-3 & Activation on HL-60 cells \\
\hline \multirow[t]{5}{*}{ Naringin } & Antioxidant & LTC4 & Inhibit the transport \\
\hline & Suppression of carcinogenesis & PI3K PKC & Inhibit the activity (in silico study) \\
\hline & Cell cycle regulation & p21, ATP & $\begin{array}{l}\text { Upregulation in } 5637 \text { bladder cancer cells inducing G1 arrest Bind } \\
\text { on PI3K binding site }\end{array}$ \\
\hline & Apoptosis & CDK2 & Inhibit the activity (in silico study) \\
\hline & Co-chemotherapeutic & $\mathrm{PgP}$ & Inhibit the activity (in silico study) \\
\hline
\end{tabular}

ATP: Adenosine tri-phosphate, PI3K: Phosphoinositide 3-kinase, ERK: Extracellular regulated protein kinases

\section{RECENT ADVANCEMENT OF FLAVONOIDS IN TREATMENT AGAINST CANCER}

The field of dietary flavonoids as antioxidants is heading towards a new era of important transformation, papers on the effects of anticancer, including polyphenols contributed to identifying as beneficial for health. Many advancements has been achieved in recent studies of flavonoids and its effect on molecular and cellular level [47].

\section{FLAVONOIDS IN CANCER METASTASIS AND CHEMOPREVENTION}

The epithelial to mesenchymal transition (EMT) pathways (involved in cancer metastasis) have been the core focus in recent days targeting cancer prevention, resistance, and apoptosis. Conversion from adhesive state to motile state of epithelial cells marks the beginning to cancer metastasis. The anticancer efficacy of the flavonoids maybe in part due to their influence on the EMT pathway.

\section{Flavonoids on molecular targets}

Targeted treatment has always been a very promising approach towards developments of new drug research. Diseases are known to have many molecular mechanism which are regulated by abundances of certain proteins,such as hormones and receptors [57].

\section{SYNERGISM EFFECTS OF FLAVONOIDS}

Naturally occurring in dietary source flavonoid, fisetin synergizes, and paclitaxel in A549 treated to non-small lung cancer cell line shows the possible molecular mechanisms and its synergism effect between the two compounds results in the development of mitotic catastrophe maybe through the promotion and formation of multipolar spindle, the expulsion through autophagy of the cells with mitotic catastrophe, a rise in the level of autophagy, which presumably underlies the conversion from the cytoprotective autophagy (elicit by PTX or FIS alone) to the autophagic cell death. The data obtained seem to be promising to light the current understanding that the manipulation of autophagy favoring the inhibition of its cytoprotective effects and the initiation of the autophagic cell death, can be viewed as a possible anticancer therapy approach [58]. Initial approaches for colon-specific drug delivery which includes time-dependent systems, $\mathrm{pH}$, microbial triggered drug delivery system and prodrugs having certain limitations, achieved few success [59]. The combination of cetuximab, an anti-EGF receptor (EGFR) monoclonal antibody and tectochrysin, a flavonoid

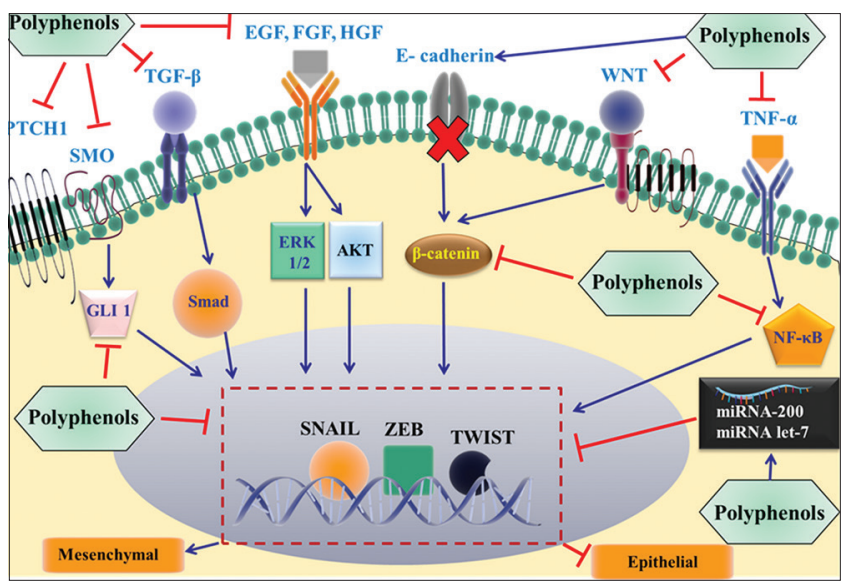

Fig. 1: Proposed mechanisms by which dietary polyphenols (phenolic acid, flavonoids, stilbenes, and lignans) inhibit EMT and cancer metastasis. The important extracellular signals are shown in the figure, and these promote by binding to individual membrane receptors from EMT, therefore activating specific EMT-inducing transcription factors (Zeb, snail, or twist). The polyphenols effect on specific proteins in signaling pathways at different levels remains to be exemplified. Transforming growth factor $\beta$, epidermal growth factor (EGF), hepatocyte growth factor, fibroblast growth factor, patched 1, smoothened, WNT, tumor necrosis factor- $\alpha$, nuclear factor-kappa B cell, glioma-associated oncogene 1, and extracellular regulated protein kinases. Akt: Protein kinase B [56]

isolated from alpinia oxyphylla Miquel on human colon cancer cell growth through further hindering of EGFR pathway [60]. Furthermore, the synergy effect by combination of Wogon flavonoids with 5-FU against renal cancer or Irinotecan (CPT-11), capecitabine, or [61] naringenin and hesperetin two citrus flavonoids commonly found in grapefruit and oranges, respectively, and four non citrus flavonoids, quercetin, genistein, galangin, and baicalein were tested in one-toone combinations and singly for their effects on growth of a human breast carcinoma cell line and cell proliferation, shows a promising results [62]. 
Synthesis flavonoids analogues toward anticancer activities

Flavonoids having an extensive biological effects and a broad coverage of pharmacological activities, however, the most important and prominent activity is their potential role to act as anticancer agents, in recent days, flavonoids along with their synthetic analogs have been largely examining in the treatment of prostate, pancreatic, cervical, breast, and ovarian cancer. The chemical synthetic analogs of flavonoids show to enhance or influence their anticancer activities [63] 8-isoprenylflavone and 7-carboxy-flavone derivatives were synthesized of their advantageous anti-inflammatory activities $[64,65]$. The derivatives of flavonoids when substituted by a heterocyclic or carbocyclic or radical, possessed good selectivity, cytotoxicity and an inhibitory effect against CDKs against various proliferative cell lines.[63] Proanthocyanidins which are condensed form of tannins, leukocyanidins, polymers of flavan-3-ols or oligomers consist of epicatechin units that are abundant type of proanthocyanidins in plants [66] which can be used for the prevention of tumor during the implantation of transitional cell [67], and are used to treat inflammatory conditions in skin,eyes and the mucosae [68]. Proanthocyanidins have several thousand to several ten thousands of molecular weights and can be a difficult factor in the intestine to be absorbed, however, synthesized sulfurcontaining proanthocyanidin oligomer which is formed during a reaction between a plant containing compound bearing $\mathrm{SH}$ group and proanthocyanidins [69]. The product formed by the two compounds results in oligomer a compound with a low molecular weight that could be easily absorbed by the humans, which can be useful for lifestylerelated diseases. Variety of chalcones analogs which possess several health benefits are also synthesized [70-73].

\section{CONCLUSIONS AND DISCUSSION}

There are thousands of different types of flavonoids found in our daily dietary components. Numerous biological activities based on cancer have been reported which includes modulation of MDR, prohibition of angiogenic process, antioxidative activity, and anticancer activities. Therefore, the majority of the research has been focused on in vitro level, excluding pharmacology into account. The fact that the availability of flavonoids in vegetables, fruits, and plants are sustainable make its promising approach toward treatment and prevention of many major clinical diseases and offers a great opportunity in drug design and development in the near future.

Isoflavone, flavanone, flavone, and flavonol all these compounds have antiproliferative activity in vitro studies, and their activity varies depending on cell type employed. However, the mass productions of flavonoids are bond to its limitation considering the fact of complicated extraction methods, less extraction yield and also burdened by the cost and difficulties of epidemiological studies. Versatile approaches and strategies are being implemented to counter such limitations.

\section{ACKNOWLEDGMENT}

The authors would like to thank the Management, Sastra University, for providing the necessary facilities and the Teaching Assistantship to Robert Lotha.

\section{REFERENCES}

1. Gupta J, Siddique YH, Beg T, Ara G, Afzal M. A review on the beneficial effect of tea polyphenols on human health. Int J Pharmacol 2008;4;314-38.

2. Lalawmpuii PC, Malsawmtluangi C, Zothanpuia, Kakoti BB. Phytochemical screening and determination of antioxidant activity of Helicia nilagirica Bedd., an ethnomedicinal plant of Mizoram, India. Asian J Pharm Clin Res 2014;7:246-9.

3. Shrishail D, Harish KH, Ravichandra H, Tulsianand G, Shruthi SD. Turmeric: Nature's precious medicine. Asian J Pharm Clin Res 2013;6;10-6.

4. Ren W, Qiao Z, Wang H, Zhu L, Zhang L. Flavonoids: Promising anticancer agents. Med Res Rev 2003;23:519-34.

5. Yao LH, Jiang YM, Shi J, Tomás-Barberán FA, Datta N, Singanusong R, et al. Flavonoids in food and their health benefits. Plant Foods Hum
Nutr 2004;59:113-22.

6. Park EJ, Pezzuto JM. Flavonoids in cancer prevention. Anticancer Agents Med Chem 2012;12:836-51.

7. Kaur R, Arora S. Alkaloids-important therapeutic secondary metabolites of plant origin. J Crit Rev 2015;2:1-8.

8. Hollman PC, Katan MB. Dietary flavonoids: Intake, health effects and bioavailability. Food Chem Toxicol 1999;37:937-42.

9. Craig WJ. Health-promoting properties of common herbs. Am J Clin Nutr 1999;70:491S-9S

10. Middleton E Jr., Kandaswami C, Theoharides TC . The effects of plant flavonoids on mammalian cells : Implications for inflammation, heart disease and cancer. J Biotech Biomater 2016;6:232-9.

11. Birt DF, Hendrich S, Wang W. Dietary agents in cancer prevention: Flavonoids and isoflavonoids. Pharmacol Ther 2001;90:157-77.

12. Webster KR. The therapeutic potential of targeting the cell cycle. Exp Opin Investig Drugs 1998;7:865-87.

13. Block G, Patterson B, Subar A. Fruit, vegetables, and cancer prevention: A review of the epidemiological evidence. Nutr Cancer 1992;18:1-29.

14. Wendeu-Foyet MG, Menegaux F. Circadian disruption and prostate cancer risk: An updated review of epidemiological evidences. Cancer Epidemiol Biomarkers Prev 2017;26:985-91.

15. Shi YQ, Fukai T, Sakagami H, Chang WJ, Yang PQ, Wang FP, et al. Cytotoxic flavonoids with isoprenoid groups from morus mongolica. J Nat Prod 2001;64:181-8.

16. Han D, Tachibana H, Yamada K. Inhibition of environmental estrogeninduced proliferation of human breast carcinoma MCF-7 cells by flavonoids. In Vitro Cell Dev Biol Anim 2001;37:275-82.

17. Preedy VR. Apoptosis. Enfield, N.H: Science Publishers; 2010.

18. Bai F, Matsui T, Ohtani-Fujita N, Matsukawa Y, Ding Y, Sakai T, et al. Promoter activation and following induction of the p21/WAF1 gene by flavone is involved in G1 phase arrest in A549 lung adenocarcinoma cells. FEBS Lett 1998;437:61-4.

19. Deep G, Agarwal R. Chemopreventive efficacy of silymarin in skin and prostate cancer. Integr Cancer Ther 2007;6:130-45.

20. Knowles LM, Zigrossi DA, Tauber RA, Hightower C, Milner JA. Flavonoids suppress androgen-independent human prostate tumor proliferation. Nutr Cancer 2000;38:116-22.

21. Hakimuddin F, Paliyath G, Meckling K. Selective cytotoxicity of a red grape wine flavonoid fraction against MCF-7 cells. Breast Cancer Res Treat 2004;85:65-79.

22. Kuntz S, Wenzel U, Daniel H. Comparative analysis of the effects of flavonoids on proliferation, cytotoxicity, and apoptosis in human colon cancer cell lines. Eur J Nutr 1999;38:133-42.

23. Wang IK, Lin-Shiau SY, Lin JK. Induction of apoptosis by apigenin and related flavonoids through cytochrome c release and activation of caspase-9 and caspase-3 in leukaemia HL-60 cells. Eur J Cancer 1999;35:1517-25

24. Csokay B, Prajda N, Weber G, Olah E. Molecular mechanisms in the antiproliferative action of quercetin. Life Sci 1997;60:2157-63.

25. Iwashita K, Kobori M, Yamaki K, Tsushida T. Flavonoids inhibit cell growth and induce apoptosis in B16 melanoma 4A5 cells. Biosci Biotechnol Biochem 2000;64:1813-20.

26. Relling MV, Evans RR, Groom S, Crom WR, Pratt CB. Saturable elimination and saturable protein binding account for flavone acetic acid pharmacokinetics. J Pharmacokinet Biopharm 1993;21:639-51.

27. Ferry R. Phase I clinical trial of the flavonoid tyrosine kinase quercetin : Pharmacokinetics for in vivo. Clin Cancer Res 1996;2;659-68.

28. Mulholland PJ, Ferry DR, Anderson D, Hussain SA, Young AM, Cook JE, et al. Pre-clinical and clinical study of QC12, a water-soluble, pro-drug of quercetin. Ann Oncol 2001;12:245-8.

29. Karimi G, Vahabzadeh M, Lari P, Rashedinia M, Moshiri M. "Silymarin", a promising pharmacological agent for treatment of diseases. Iran J Basic Med Sci 2011;14:308-17.

30. Zhao C, Feng X, Tang T, Qiu L. Isolation and expression analysis of CYP9A11 and cytochrome P450 reductase gene in the beet armyworm (Lepidoptera: Noctuidae). J Insect Sci 2015;15:122.

31. Nagao A, Seki M, Kobayashi H. Inhibition of xanthine oxidase by flavonoids. Biosci Biotechnol Biochem 1999;63:1787-90.

32. Senderowicz AM. Flavopiridol: The rst cyclin-dependent kinase inhibitor in human clinical trials. Invest New Drugs 1999;17:313-20.

33. Senderowicz AM. Development of cyclin-dependent kinase modulators as novel therapeutic approaches for hematological malignancies. Leukemia 2001;15:1-9.

34. Markovits J, Linassier C, Fossé P, Couprie J, Pierre J, Jacquemin-Sablon A, et al. Inhibitory effects of the tyrosine kinase inhibitor genistein on mammalian DNA topoisomerase II. Cancer Res 1989;49:5111-7. 
35. Bailly C. Topoisomerase I poisons and suppressors as anticancer drugs. Curr Med Chem 2000;7:39-58.

36. Yoon G, Kang BY, Cheon SH. Topoisomerase I inhibition and cytotoxicity of licochalcones A and E from glycyrrhiza inflata. Arch Pharm Res 2007;30:313-6.

37. Yu JS, Kim AK. Wogonin induces apoptosis by activation of ERK and p38 MAPKs signaling pathways and generation of reactive oxygen species in human breast cancer cells. Mol Cells 2011;31:327-35.

38. Takahashi T, Kobori M, Shinmoto H, Tsushida T. Structure-activity relationships of flavonoids and the induction of granulocytic- or monocytic-differentiation in HL60 human myeloid leukemia cells. Biosci Biotechnol Biochem 1998;62:2199-204.

39. Adlercreutz H. Phytoestrogens: Epidemiology and a possible role in cancer protection. Environ Health Perspect 1995;103:103-12.

40. Halliwell B, Gutteridge JM. Role of free radicals and catalytic metal ions in human disease: An overview. Methods Enzymol 1990;186:1-85.

41. Halliwell B. Free radicals and antioxidants: A personal view. Nutr Rev 1994;52:253-65.

42. Nijveldt RJ, van Nood E, van Hoorn DE, Boelens PG, van Norren K, van Leeuwen PA, et al. Flavonoids: A review of probable mechanisms of action and potential applications. Am J Clin Nutr 2001;74:418-25.

43. Tosetti F, Ferrari N, De Flora S, Albini A. Angioprevention': Angiogenesis is a common and key target for cancer chemopreventive agents. FASEB J 2002;16:2-14.

44. Kioka N, Hosokawa N, Komano T, Hirayoshi K, Nagata K, Ueda K, et al. Quercetin, a bioflavonoid, inhibits the increase of human multidrug resistance gene (MDR1) expression caused by arsenite. FEBS Lett 1992;301:307-9.

45. Kiessling R, Klein E, Wigzell H. Natural killer cells in the mouse. Eur J Immunol 1975;5:112-7.

46. Sutlu T, Alici E. Natural killer cell-based immunotherapy in cancer: Current insights and future prospects. J Intern Med 2009;266:154-81.

47. Russo GL, Tedesco I, Spagnuolo C, Russo M. Antioxidant polyphenols in cancer treatment: Friend, foe or foil? Semin Cancer Biol 2017;46:1-3.

48. Rafiq RA, Quadri A, Nazir LA, Peerzada K, Ganai BA, Tasduq SA, et al. A potent inhibitor of phosphoinositide 3-kinase (PI3K) and mitogen activated protein (MAP) kinase signalling, quercetin $(3,3$ ', 4', 5, 7-pentahydroxyflavone) promotes cell death in ultraviolet (UV)-Birradiated B16F10 melanoma cells. PLoS One 2015;10:e131253.

49. Tedesco I, Russo M, Bilotto S, Spagnuolo C, Scognamiglio A, Palumbo R, et al. Dealcoholated red wine induces autophagic and apoptotic cell death in an osteosarcoma cell line. Food Chem Toxicol 2013;60:377-84

50. Raina K, Agarwal C, Wadhwa R, Serkova NJ, Agarwal R. Energy deprivation by silibinin in colorectal cancer cells: A double-edged sword targeting both apoptotic and autophagic machineries. Autophagy 2013;9:697-713

51. Khan HY, Zubair H, Faisal M, Ullah MF, Farhan M, Sarkar FH, et al. Plant polyphenol induced cell death in human cancer cells involves mobilization of intracellular copper ions and reactive oxygen species generation: A mechanism for cancer chemopreventive action. Mol Nutr Food Res 2014;58:437-46.

52. Dai F, Liu GY, Li Y, Yan WJ, Wang Q, Yang J, et al. Insights into the importance for designing curcumin-inspired anticancer agents by a prooxidant strategy: The case of diarylpentanoids. Free Radic Biol Med 2015;85:127-37.

53. Jing X, Cheng W, Wang S, Li P, He L. Resveratrol induces cell cycle arrest in human gastric cancer MGC803 cells via the PTEN-regulated PI3K/Akt signaling pathway. Oncol Rep 2016;35:472-8.

54. Xie J, Yun JP, Yang YN, Hua F, Zhang XW, Lin H, et al. A novel ECG analog 4-(S)-(2,4,6-trimethylthiobenzyl)-epigallocatechin gallate selectively induces apoptosis of B16-F10 melanoma via activation of autophagy and ROS. Sci Rep 2017;7:42194.

55. Shin SY, Lee JM, Lee MS, Koh D, Jung H, Lim Y, et al. Targeting cancer cells via the reactive oxygen species-mediated unfolded protein response with a novel synthetic polyphenol conjugate. Clin Cancer Res 2014;20:4302-13

56. Amawi H, Ashby CR, Samuel T, Peraman R, Tiwari AK. Polyphenolic nutrients in cancer chemoprevention and metastasis: Role of the epithelial-to-mesenchymal (EMT) pathway. Nutrients 2017;9:911.

57. Meiyanto E, Hermawan A, Anindyajati A. Natural products for cancertargeted therapy: Citrus flavonoids as potent chemopreventive agents. Asian Pacific J Cancer Prev 2012;13:427-36.

58. Klimaszewska-Wisniewska A, Halas-Wisniewska M, Tadrowski T, Gagat M, Grzanka D, Grzanka A, et al. Paclitaxel and the dietary flavonoid fisetin: A synergistic combination that induces mitotic catastrophe and autophagic cell death in A549 non-small cell lung cancer cells. Cancer Cell Int 2016;16:10

59. Kumar M, Sasmita S. Colon targeted drug delivery system-an approach for treating colonic ailments. J Crit Rev 2015;2:1-2

60. Park MH, Hong JE, Hwang CJ, Choi M, Choi JS, An YJ, et al. Synergistic inhibitory effect of cetuximab and tectochrysin on human colon cancer cell growth via inhibition of EGFR signal. Arch Pharm Res 2016;39:721-9.

61. Hirata Y, Tatsu M, Amano C, Kawaratani Y, Hirata1 M, Ohmomo Y. Synergistic antitumor effect of genitinib (Iressa) with flavonoids from the root on the non-small cell lung cells. Open Plant Sci J 2017;10;62-9.

62. So FV, Guthrie N, Chambers AF, Moussa M, Carroll KK. Inhibition of human breast cancer cell proliferation and delay of mammary tumorigenesis by flavonoids and citrus juices. Nutr Cancer 1996;26:167-81.

63. Liu HL, Jiang WB, Xie MX. Flavonoids: Recent advances as anticancer drugs. Recent Pat Anticancer Drug Discov 2010;5:152-64.

64. Fr N, Schutze F. (12) United States Patent; 2005; p. 5-11.

65. Cotter RJ. (12) United States Patent No. 5,908,690; 2003. p. 1.

66. Nandakumar V, Singh T, Katiyar SK. Multi-targeted prevention and therapy of cancer by proanthocyanidins. Cancer Lett 2008;269:378-87.

67. Budiman ES, Zhang S. United States (12) No. 13. 14. 15. 16. 17. 18. 19. 20. 21. 22. 23. 24. 25. 26. 26. 27. 28. 29. 30. 31. 32; 2014. p. 1.

68. Application F, Data P, Ciattini R. (19) United States; 2008.

69. Bstract A. (19) United States (12) Patent Application Publication; 2002. p. 1 .

70. Llp B, Docketing P, Street E. (19) United States (12); 2008.

71. El-toumy SA, Salib JY, Shafik NH, Elkarim AS, Farag AA. New flavonoids from the aerial parts of polygonum equisetiforme sm (Polygonaceae). Int J Pharm Pharm Sci 2017;9:166-70.

72. Sambandam B, Thiyagarajan D, Ayyaswamy A, Raman P, Kulasekaran J, Venkatasamy $\mathrm{H}$, et al. Extraction and isolation of flavonoid quercetin from the leaves of Trigonella foenum-graecum and their anti-oxidant activity. Int J Pharm Pharm Sci 2016;8:120-4.

73. Sundaram KM, Nanthini UR, Yadav SA, Thangavel S. Anti-oxidant and anti-microbial activities of synthetic 3-formyl, 7-flavonol intermediates obtained by microwave assisted technique. Int $\mathrm{J}$ Pharm Pharm Sci 2015;7:124-8. 